\title{
Inefficient immune response is associated with microbial permissiveness in juvenile oysters affected by mass mortalities on field
}

\author{
De Lorgeril Julien ${ }^{1,{ }^{*}}$, Escoubas Jean Michel ${ }^{6}$, Loubiere Vincent ${ }^{6}$, Pernet Fabrice ${ }^{2}$, Le Gall Patrik ${ }^{3}$, \\ Vergnes Agnes ${ }^{1}$, Aujoulat Fabien ${ }^{4}$, Jeannot Jean-Luc ${ }^{5}$, Jumas-Bilak Estelle ${ }^{4}$, Got Patrice ${ }^{5}$, Gueguen \\ Yannick ${ }^{1}$, Destoumieux-Garzòn Delphine ${ }^{1}$, Bachère Evelyne ${ }^{1}$
}

${ }^{1}$ IHPE, Université de Montpellier, CNRS, Ifremer, Université de Perpignan, Via Domitia, France

2 Ifremer, LEMAR UMR6539, CNRS/UBO/IRD/Ifremer, F-29280, Plouzané, France

3 Ifremer, MARBEC UMR 9190 (IRD, Ifremer, UM, CNRS), Avenue Jean Monnet, 34203, Sète, France

${ }^{4}$ Equipe Pathogènes Hydriques, Santé, Environnements, UMR 5569 Hydrosciences Montpellier, U.F.R des Sciences Pharmaceutiques et Biologiques and Université Montpellier, Montpellier, France

${ }^{5}$ UMR 9190 MARBEC, IRD-CNRS- Université Montpellier-Ifremer, Avenue Jean Monnet, F-34200, Sète, France

* Corresponding author : Julien de Lorgeril, email address : jdelorge@ifremer.fr

\begin{abstract}
:
Since 2008, juvenile Crassostrea gigas oysters have suffered from massive mortalities in European farming areas. This disease of complex etiology is still incompletely understood. Triggered by an elevated seawater temperature, it has been associated to infections by a herpes virus named OsHV-1 as well as pathogenic vibrios of the Splendidus clade. Ruling out the complexity of the disease, most of our current knowledge has been acquired in controlled experiments. Among the many unsolved questions, it is still ignored what role immunity plays in the capacity oysters have to survive an infectious episode. Here we show that juvenile oysters susceptible to the disease mount an inefficient immune response associated with microbial permissiveness and death. We found that, in contrast to resistant adult oysters having survived an earlier episode of mortality, susceptible juvenile oysters never exposed to infectious episodes died by more than $90 \%$ in a field experiment. Susceptible oysters were heavily colonized by OsHV-1 herpes virus as well as bacteria including vibrios potentially pathogenic for oysters, which proliferated in oyster flesh and body fluids during the mortality event. Nonetheless, susceptible oysters were found to sense microbes as indicated by an overexpression of immune receptors and immune signaling pathways. However, they did not express important immune effectors involved in antimicrobial immunity and apoptosis and showed repressed expression of genes involved in ROS and metal homeostasis. This contrasted with resistant oysters, which expressed those important effectors, controlled bacterial and viral colonization and showed $100 \%$ survival to the mortality event. Altogether, our results demonstrate that the immune response mounted by susceptible oysters lacks some important immune functions and fails in controlling microbial proliferation. This study opens the way to more holistic studies on the "mass mortality syndrome", which are now required to decipher the sequence of events leading to oyster mortalities and determine the relative weight of pathogens, oyster
\end{abstract}


genetics and oyster-associated microbiota in the disease.

\section{Highlights}

- Juvenile oysters susceptible to the disease mount an inefficient immune response associated with microbial permissiveness and death. Susceptible oysters were heavily colonized by OsHV-1 herpes virus as well as bacteria including vibrios potentially pathogenic for oysters. Adult oysters resistant to the disease expresses important immune effectors, controlled bacterial and viral colonization and survived to the mortality event.

Keywords: Host pathogen interaction, Innate immunity, Invertebrate, Mollusk, In situ mortality, Total bacteria, Crassostrea gigas 
58 Over the past twenty years, recurrent mortality outbreaks have been recorded in the 59 production of Crassostrea gigas oysters [1, 2]. Since 2008, mortalities of high intensity and 60 wide geographic distribution have massively affected juvenile stages [3-9]. It is recognized 61 that this mortality syndrome refers to a multifactorial disease highly dependent on 62 temperature which is the main environmental stressor triggering the disease [4, 10-13]. 
This disease of complex etiology has motivated a broad number of studies and results suggested that a combination of etiological agents, which include a virus and bacteria, are responsible for the disease $[3,4,14-16]$. Among them, the most frequently incriminated are a herpesviruses (OsHV-1 $\mu$ Var) and pathogenic populations of vibrios of the Splendidus clade [4, 16-20]. Recent works have demonstrated that OsHV-1 load correlated to oyster mortality in the wild $[3,16,21,22]$. However, the relative role of the diverse pathogenic agents in the disease development, their interaction patterns and their dynamics during pathogenesis in natural environment are largely unknown, which makes the disease difficult to understand, predict and control. Beside an obvious role for pathogens, the current literature shows that the severity of the disease is largely depended on host genetics and phenotypic plasticity. On the one hand, Azema et al. showed that resistance to the disease is highly dependent on the oyster genetics (from 0 to $100 \%$ of mortality in controlled conditions) and is a high heritable trait [23]. On the other hand, a series of environmental and developmental factors were shown to affect disease expression over oyster lifespan. These include oyster age, energetic reserves, food quality and farming practices $[11,12,24]$. Both controlled laboratory experiments and field experiments in which oysters were exposed to OsHV-1 showed that juvenile oysters were more susceptible to the disease than adults [25, 26]. Consistently, oyster immune capabilities were shown to change according to oyster developmental stages, abiotic stressors (salinity, temperature and air exposure) and pathogens encountered (viruses and bacteria) [27]. Particularly, experimental infections showed that juvenile and adult oysters mount distinct immune responses against viral and bacterial pathogens associated to the disease [25, 28]. This immune plasticity is probably underpinned by the diversity of immune genes, which have been the subject of massive expansion in C. gigas [27], but whose patterns of expression remain poorly characterized.

For this reason, understanding the susceptibility of juveniles to mass mortalities requires to conduct field studies that take in account the oyster immune response to abiotic factors and natural pathobiome. A few field studies have been already conducted, but it is still unknown whether the susceptibility of juvenile oysters to mass mortalities is due to an immature immune system which would imperfectly sense pathogens or an incapacity to mount an appropriate immune response [21, 29]. In other words, understanding the role of immunity in the capacity of oysters to resist to the disease remains an important question to address to get deeper insight into this complex disease.

With that objective, we conducted here a field study in which specific pathogen-free juvenile oysters ( 8 months old), susceptible to the disease, were immersed in an oyster farms of the 
Thau lagoon (south of France) during an episode of mass mortality. Adult oysters (18 months old and having survived a previous infectious episode) were used as a resistant control. The immune response of the susceptible juvenile oysters and their colonization by microbes including potential pathogens were monitored at four time points before and during the infectious episode and compared to that of the resistant oysters maintained in the same environment. Results showed that the susceptible oysters, which died by more than $90 \%$, were readily colonized by OsHV-1 and bacteria including vibrios of the Splendidus clade during the infectious episode, as opposed to the resistant ones which maintained a stable bacterial load, controlled pathogens and survived. Transcriptome analyses revealed that the susceptible juvenile oysters mounted an inefficient immune response which differed from the efficient immune status of the resistant oysters. Altogether, our results show that the susceptibility of juvenile oysters is related to inefficient immune responses leading to microbial permissiveness and death.

\section{Materials and Methods}

\section{Oyster sampling during in situ mortality}

Two different cohorts of Crassostrea gigas oysters were used for in situ experimentation. Firstly, 18 months old oyster were produced in June 2008 at the Ifremer oyster hatchery in La Tremblade (Charente Maritime, France). They were deployed in Thau lagoon in March 2009 in a site impacted by oyster mortality (latitude: 43.379087 ; longitude: 3.571483 ). Secondly, 8 months old oysters were produced in August 2009 at the Ifremer oyster hatchery in La Tremblade (Charente Maritime, France). Genitors used to produce the two oyster cohorts were collected from the same location (La Tremblade, France). They were deployed the 12 March 2010 in the same site as the 18 months old oysters. In Thau lagoon, 8 months old oysters were collected at four dates (April 6, 12, 26 and 29, shell length $15 \pm 3 \mathrm{~mm}$ ) and 18 months old oysters were collected at one date (April 29, shell length $62 \pm 9 \mathrm{~mm}$ ). A temperature monitoring was performed and mortalities were recorded. For each date and for each oyster cohort, oysters were sampled (whole oyster flesh, 4 pools of 7 oysters) and snapfrozen with liquid nitrogen and stored at $-80^{\circ} \mathrm{C}$ until RNA and DNA extractions (for gene expression analysis and pathogen quantification), intravalvular fluid was collected from other oysters for cytometry analysis (10 individual oysters per condition, 100-400 $\mu 1$ per individual fixed in $2 \%$ formalin (Sigma-Aldrich)), and six other oysters were collected to determine 
abundances of culturable bacteria. In addition, environmental seawater was collected and fixed in $2 \%$ formalin (Sigma-Aldrich) at each date during mortality (50ml) for cytometry analysis, and sea water temperature was recorded every day (autonomous CTD multiparameter recorders, NKE Instrumentation).

\section{RNA extraction and cDNA synthesis}

RNA extraction was performed following the TRIzol Reagent manual according to manufacturer's instructions (Invitrogen) from frozen oyster powder (Retsch, Mixer Mill MM400 with liquid nitrogen). Frozen oyster powder $(20 \mathrm{mg}$ ) was homogenized in $1 \mathrm{ml}$ of Trizol by vortexing between $1-2 \mathrm{~h}$ at $4{ }^{\circ} \mathrm{C}$. Prior to extraction, insoluble materials were removed by centrifugation at $12000 \mathrm{xg}$ for $10 \mathrm{~min}$ at $4^{\circ} \mathrm{C}$. Next, RNA samples were treated with 5 units of DNase I (Invitrogen) to eliminate DNA contamination, followed by heat inactivation $\left(10 \mathrm{~min}\right.$ at $\left.65^{\circ} \mathrm{C}\right)$. Finally, RNA was precipitated with $100 \%$ isopropyl alcohol and $3 \mathrm{M} \mathrm{Na}$-acetate, washed with $75 \%$ cold ethanol and dissolved in $50 \mu \mathrm{l}$ of RNase-free water. Quantification and integrity of total RNA was checked using a NanoDrop spectrophotometer (Thermo Fisher Scientific) and 1.5\% agarose gel electrophoresis, respectively. Total RNA (3 $\mu \mathrm{g})$ was reverse transcribed in $20 \mu \mathrm{l}$ using the Moloney Murine Leukemia Virus Reverse Transcriptase (MMLV-RT) according to manufacturer's instructions (Invitrogen).

\section{DNA extraction}

For the genomic DNA (gDNA) extractions, $20 \mathrm{mg}$ of frozen oyster powder was homogenized in $500 \mu \mathrm{l}$ of lysis buffer $(100 \mathrm{mM} \mathrm{NaCl}, 10 \mathrm{mM}$ Tris-HCl, $25 \mathrm{mM}$ EDTA, $0.5 \%$ SDS and 0.1 $\mathrm{mg} / \mathrm{ml}$ proteinase $\mathrm{K}, \mathrm{pH} 8$ ) for $4 \mathrm{~h}$ at $50^{\circ} \mathrm{C}$, followed by phenol/chloroform extraction and precipitation with $100 \%$ ethanol for $2 \mathrm{~h}$ at $-80^{\circ} \mathrm{C}$. gDNA was spooled with a pipette tip and washed in tubes containing 75\% ethanol, vacuum-dried, dissolved in DNase-free water and treated with RNAse (Invitrogen) $1 \mathrm{mg} / \mathrm{ml}$ for $30 \mathrm{~min}$ at $37^{\circ} \mathrm{C}$. A second precipitation was performed with $100 \%$ isopropyl alcohol and $3 \mathrm{M}$ Na-acetate and the gDNA pellet was resuspended in DNase-free water. Quantification and integrity of gDNA was checked using a NanoDrop spectrophotometer (Thermo Fisher Scientific) and $0.8 \%$ agarose gel electrophoresis, respectively.

\section{Gene expression and pathogens quantification by quantitative PCR}

qPCR analysis were performed for two objectives: (i) for assessment of the relative expressions of 88 genes of interest of the oyster from oyster cDNA, (ii) and for assessment of 
the relative abundance of two pathogens (OsHV-1 and Vibrio splendidus) from oyster gDNA. qPCR assays were carried out on the Light-Cycler 480 System (Roche Diagnostics GmbH). The $5 \mu \mathrm{l}$-volume reaction consisted of $1 \mathrm{X}$ Light-Cycler 480 master mix, $0.5 \mu \mathrm{M}$ of each primer (Eurogentec) and $1 \mu \mathrm{l}$ of cDNA diluted at $1 / 8$ in sterile ultra-pure water for gene expression analyses, and $1 \mu \mathrm{l}$ of $\mathrm{gADN}$ diluted at $20 \mathrm{ng} / \mu \mathrm{l}$ in sterile ultra-pure water for pathogen quantifications. qPCR assays were performed in triplicate, and primer pair efficiencies (E) were calculated by five serial dilutions of pooled cDNA or gDNA ranging from 1/2 to $1 / 64$ in sterile ultra-pure water, in duplicate with each primer pair. Primer pair efficiencies were calculated from the given slopes in LightCycler software according to the equation: $\mathrm{E}=10[-$ 1/slope]. List of primers used to amplify the 88 immune related genes and the three reference genes and primers used to amplify the two pathogens $[30,31]$ and the reference gene are presented in Supplementary table 1. qPCR assays were submitted to an initial denaturation step of $15 \mathrm{~min}$ at $95^{\circ} \mathrm{C}$ followed by an amplification of the target cDNA (35 cycles of denaturation at $95^{\circ} \mathrm{C}$ for $10 \mathrm{~s}$, annealing at $57^{\circ} \mathrm{C}$ for $20 \mathrm{~s}$ and extension time at $72^{\circ} \mathrm{C}$ for $25 \mathrm{~s}$ ) and fluorescence detection. Relative expression of immune relative genes was calculated using the $2^{-\Delta \Delta \mathrm{Ct}}$ method [32], using the mean of the measured threshold cycle $(\mathrm{Ct})$ values of three constitutively expressed genes (Cg-EF1 [GenBank AB122066], Cg-RPL40 [GenBank FP004478] and Cg-RPS6 [GenBank HS119070]) to normalize the measured Ct values of target genes. Moreover, relative abundance of the two pathogens was obtained with the same method but using a single copy encoded gene (C. gigas bactericidal permeability-increasing protein, $C g$-bpi) as reference [GenBank: AY165040].

\section{Total Bacteria quantification}

Total bacterial cells were enumerated by flow cytometry from intravalvular fluids of 10 individual oysters per condition and from environmental seawater (previously fixed in formalin 2\%, Sigma-Aldrich) using SYBR Green I (Molecular Probes) according to the protocol described by [33], modified by [34]. Samples were analyzed using a FACS Calibur flow cytometer (from $20 \mu 1$ per sample, Becton Dickinson) equipped with an air-cooled argon laser (488 nm, $15 \mathrm{~mW})$. Stained bacterial cells, excited at $488 \mathrm{~nm}$, were enumerated according to their right angle light scatter (RALS) and green fluorescence (FL1) and measured using a $530 / 30 \mathrm{~nm}$ filter. Fluorescent beads (1-2 $\mu \mathrm{m}$, Polysciences) were systematically added to each sample to standardize the flow cytometer settings and true count beads (Becton Dickinson) were added to determine the volume analyzed. Bacterial cells tend to cluster into two distinct fractions based on differences in individual cell fluorescence (related to their nucleic acid 
content) and in the side and forward light scatter signal (related to their cell size). These fractions are defined as HNA cells (high nucleic acid content) and LNA cells (low nucleic acid content), respectively [35, 36]. List-mode files were analyzed using BD Cell quest Pro software (Becton Dickinson).

Additionally, abundances of culturable bacteria in whole oyster flesh were determined by CFU counting. Oysters were sacrificed and ground in sterile seawater (10 mL/g of wet tissue). The total culturable bacteria flora was quantified (CFU/mg of tissue) from six individual oysters using serial dilutions on Marine agar (Becton Dickinson, Difco).

\section{Statistical analysis}

To get a global vision during oyster mortality of the modulated oyster genes according to in situ conditions, qPCR data of all differentially expressed genes (one-way ANOVA, $p<0.05$, Satistica software version 7.1) were analyzed by a hierarchical clustering with Multiple Array Viewer software (version 4.6.2, http://www.tm4.org/mev/) using average linkage clustering with Spearman rank correlation as the default distance metric.

Differences in microbial load between susceptible and resistant oysters at each date during mortality (pathogens, total bacteria in intravalvular fluids, and culturable bacteria) were determined by Mann-Whitney U test ( $p<0.05$, GraphPad Prism 6).

\section{Results and discussions}

\section{Oyster mortalities on field}

In order to study oysters with contrasted phenotypes to mortality events, we used two cohorts of Crassostrea gigas oysters in field experiment. On the one hand, 8 months old specific pathogen free oysters directly issued from hatchery and susceptible to the disease [10] were immersed in a farm of the Thau lagoon, south of France a few days before a mass mortality event started (March 12 $\left.2^{\text {th }}, 2010\right)$. One the other hand, 18 months old oysters having survived an infectious episode one year before in the same farm were used as resistant controls. Mortalities were monitored on both cohorts at different time points and temperature was measured all over the experiment. Mortalities started when seawater temperature exceeded $16^{\circ} \mathrm{C}$, which is considered the low thermic threshold for in situ mortality outbreak $[10,11]$. As expected from our experimental design, mortalities were observed only on 8 months old oysters exposed for the first time to an infectious environment. A sharp rise in mortality was observed, which reached $90 \%$ in only two weeks (from $12^{\text {th }}$ to $29^{\text {th }}$ of April) 
(Figure 1). Conversely, 18 months old oysters having survived a previous infectious episode were only marginally affected, as indicated by less than $5 \%$ cumulative mortality by the end of the experiment (Figure. 1).

This is in line with previous observations showing that OsHV-1-associated mortalities affect preferentially spat and juvenile stages [24, 25, 37]. It also agrees with a previous study showing that one-year-old oysters from one same origin were highly resistant (7\% mortality) when naturally selected for resistance to the disease whereas they died massively when they have never been exposed to the disease before [11]. This was attributed to the strong genetic basis of the resistance to the disease $[25,28]$. However, like in our present experiment, other important life history traits often differentiate oyster cohorts. Indeed, here adults have been maintained in the Thau lagoon for more than a year. Not only did they pass though the major selective filter of the disease (brought by a similar infectious environment) one year before, but they have been confronted to an environment that can have modified their physiology and associated microbiota, and/or primed their immune system as recently shown by Lafont et al. [38]. Additionally, potential trade-offs between immune function, growth and reproduction investment could also influence the resistance to the disease. Thus, both genetic factors and phenotypic plasticity could influence the surviving capacity of adult oysters in our experiment, but we cannot evaluate the relative weight of these two factors in the resistance from our data.

\section{Oysters susceptible to the disease are highly permissive to bacterial colonization during} in situ mortality outbreak

To determine the changes in bacterial abundance occurring in oysters with contrasted resistance, we compared total bacterial loads in the susceptible (S, 8 months old oysters) and resistant (R, 18 months old oysters) oysters during the mortality event. Bacterial load was first measured by flow cytometry in intravalvular fluids of oysters, a compartment at the hostenvironment interface that is potentially altered during bivalve diseases [39]. In addition, bacterial load was measured in seawater surrounding oysters: no significant change was observed between the early (April 26 ${ }^{\text {th, }}$ 2010) and late stages (April 29 $9^{\text {th, }}$ 2010) of the mortality event with $\sim 6.10^{6}$ bacteria/ml of seawater at both time points (Figure 2A). Resistant oysters did not show any significant bacterial colonization of their intravalvular fluids as indicated by a constant bacterial load (from $2.10^{6}$ to $1.10^{7}$ bacteria/ml), similar to that of seawater, all over the mortality event. Conversely, susceptible oysters, showed a high intravalvular fluid bacterial load, up to $3.10^{8}$ bacteria/ml, reaching 15 to 19 times the load measured in resistant 
oysters, both at early and late stages of the mortality outbreak (Mann-Whitney U test, $p<0.05)$. Those results showed that susceptible oysters are significantly more permissive to bacterial colonization than resistant oysters. Similar results were observed when we quantified culturable bacteria into oyster flesh. The bacterial load in resistant oysters remained constant over time, whereas the bacterial load of susceptible oysters was always significantly higher compared to resistant ones $\left(2.10^{6}\right.$ to $10^{7} \mathrm{CFU} / \mathrm{g}$ versus 1 to $2.10^{5} \mathrm{CFU} / \mathrm{g}$, Mann-Whitney test, $p<0.05$ ) (Figure 2B). Previous studies have already shown that Vibrio colonization precedes oyster death [22] and that the stability of oyster microbiota influences the resistance of pathogens [40]. However, these results show for the first time an intricate link between oyster health status and bacterial colonization of both oyster flesh and body fluids. This event is characterized by an overall stability in resistant oysters as opposed to a massive colonization in susceptible oysters. Investigating the kinetic of bacterial colonization in resistant and susceptible oysters before the occurrence of the first mortalities should be performed in the future to evaluate the importance of bacterial colonization in the overall pathogenic process.

\section{Susceptible but not resistant oysters are heavily colonized by pathogens}

As oyster mortality outbreaks have been associated to both a herpesvirus (OsHV-1 $\mu$ var) and vibrios of the Splendidus clade [4, 11, 15, 19,41], we quantified their respective load in oyster flesh by relative quantitative PCR. For vibrios, we used $V$. tasmaniensis-specific primers designed on the sequence of the LGP32 pathogenic strain (Splendidus clade), which was isolated during an in situ oyster mortality event [17]. This vibrio strain was used in experimental challenges of oysters in different studies [4, 42]. The V. tasmaniensis load was found to increase in susceptible oysters before mortality started and reached a maximum when mortality reached 90\%, on April 29 ${ }^{\text {th }}, 2010$ (Figure 3A) (Mann-Whitney U test, $p<0.05$ ). The oyster colonization by pathogenic strains of vibrios before the mortality outbreak is in agreement with previous work [19, 22]. Concomitantly, OsHV-1 colonized tissues of susceptible oysters (Figure 3B). A gradual increase in viral load was indeed observed all over the time course. This increase became significant on April $26^{\text {th }}, 2010$ when mortality started. The concomitant colonization of oyster flesh by OsHV-1 and vibrios of the Splendidus clade preceding oyster death has been reported in different environments (Atlantic and Mediterranean) [11, 15] and seems to be the hallmark of the disease. Thus, together with previous studies $[11,15,22]$, our data confirm the hypothesis of a temperature-dependent polymicrobial disease in which both an OsHV-1 virus and pathogenic populations of vibrios cooperate to kill oysters. Additionally, our results indicated that adult oysters which survived 
the disease outbreaks were not tolerant but indeed resistant to the main pathogens associated to the disease, which failed to colonize their intravalvular fluids and tissues. In the future, moving to a non-candidate approach for pathogen monitoring in resistant and susceptible genetic backgrounds appears essential for a complete understanding of the disease. Indeed, not only did we observe here major bacterial proliferation in susceptible oysters (Figure 2), but also recent studies reported that the stability of oyster/microbiota associations influences the resistance of oysters to stress or invasion by pathogens [40, 43, 44]. Thus, to clearly understand the role of microbiota in the pathogenesis, it will be important to analyze its structure and dynamics throughout the infectious process.

\section{A set of immune genes specifically expressed in resistant oysters}

To unravel the difference in permissiveness between resistant and susceptible oysters, we compared their immune status during the disease outbreak by analyzing the expression pattern of genes previously described as key components of the oyster response to infectious challenges [45, 46]. High-throughput RT-qPCR revealed that 54 immune-related genes out of 88 were differentially expressed (one-way ANOVA, $p<0.05$ ) between the two oyster cohorts (resistant adults and susceptible juveniles) or between the different sampling times (i.e. before or during mortalities) (Figure 4). On one dimension, hierarchical clustering of differentially expressed genes separated samples into three clusters according to conditions (A-C): samples from susceptible oysters fell into two clusters, before (cluster A) and during mortalities (cluster C) whereas resistant oysters sampled during mortalities fell into a third cluster (cluster B).

On the other dimension, genes also fell into 3 clusters according to expression (1-3). Genes from cluster 2 were particularly interesting as they were expressed at higher ratios in resistant oysters preferentially (cluster B) (Figure 4). Remarkably, cluster 2 is composed of genes encoding pathogen recognition proteins (lectins, and Complement C1q) and immune effectors including two antimicrobial peptides/proteins (lysozyme, proline rich peptide), a metalloproteinase inhibitor and a heat shock protein, known to participate in oyster immune response to bacterial infections [47-53]. Importantly, Cluster 2 also contains genes encoding proteins involved in apoptosis (caspase-3) and autophagy (beclin), two processes that have been described to play a key role in oyster response to viral and bacterial challenges $[54,55]$. Since cluster 2 is specific to resistant oysters, which are neither colonized by OsHV-1 nor by $V$. tasmaniensis (Figure 3), it is tempting to speculate that high expression of those antibacterial and antiviral genes, either alone or in combination, plays an important role in the 
control of pathogens and resistance to the disease. However, due to the design of the experimental protocol, we do not have access to the dynamic of expression in resistant oysters all along the mortality event (resistant oysters have been collected at the end of experiment only). Thus, we cannot determine whether the high expression of genes from cluster 2 is due to an induction of gene expression in resistant oysters as observed in experimental infection of adult oysters by OsHV-1 [28] or whether it is due to a high constitutive level of expression as observed in resistant oyster line compared to susceptible oyster line [56]. Indeed, constitutive frontloading of stress tolerance genes was shown to maintain physiological resilience during frequently encountered environmental stress in other species, particularly corals [57]. In the future, investigating the dynamics of expression of genes from cluster 2 in field experiments should help better understand the respective role of the antiviral and antibacterial immune responses in controlling the pathogens associated to the syndrome.

\section{Oysters susceptible to the disease are able to sense pathogen colonization and trigger an} immune response

Importantly, gene expression data revealed that susceptible oysters were able to actively express immune genes when confronted to pathogens. Particularly, genes from cluster 1 were highly induced in susceptible oysters over the mortality outbreak whereas resistant oysters only poorly expressed those genes during mortalities (Figure 4). These genes encode notably proteins involved in pathogen recognition (galectin) and immune signaling pathways $(\mathrm{Cg}$ Myd88, NF-kappa-B inhibitor, MAP kinase-interacting serine/threonine-protein kinase, interleukin 17), and their overexpression has been associated with experimental challenges by either bacteria or viruses [28, 58-61] as well as in situ infections of $C$. gigas oysters [62, 63]. These data clearly showed that susceptible oysters are able to detect pathogens and mount an immune response.

However, a group of genes (cluster 3) showed decreased expression over disease development in susceptible oysters (Figure 4). On the contrary, resistant oysters highly expressed cluster 3 genes during the mortality event. This contrast between resistant and susceptible oysters suggests that repressed expression of cluster 3 genes is detrimental in susceptible oysters. Genes from cluster 3 involved in the antioxidant system (i.e. Super Oxyde Dismutase, Glutathione S-transferase) and metal homeostasis (i.e. Metallothioneins) have been previously reported to be down regulated in oysters undergoing mass mortalities $[60,62]$ as well as in experimental infections by OsHV-1 or pathogenic vibrios [28, 59]. ROS and metal homeostasis were shown to play a major role in controlling vibrio infections, particularly in 
the $C$. gigas/V. tasmaniensis LGP32 pathogenic interaction [42]. Disruption of those important homeostatic processes might therefore have detrimental consequences on the host and contribute to the massive increase in bacterial colonization observed in susceptible oysters (Figure 2).

Altogether, our results showed that resistant and susceptible oysters, confronted to a mortality outbreak in the field can be distinguished by distinct molecular immune signatures during pathogenesis. Moreover, we showed that the although susceptible oysters juveniles sense pathogens and signal an immune response, they do not express important functions related to antimicrobial responses, apoptosis, ROS and metal homeostasis, thereby failing to control pathogens and subsequent mortalities. The reason why pathogen sensing and immune signaling does not result in pathogen control in juveniles remains to be explored both from the host side looking closer at the genetic basis and the phenotypic plasticity of resistance and from the pathogen side, as they could repress important host defense mechanisms for their benefit.

\section{Conclusion}

By exposing oysters with fully contrasted resistance to a field mortality event and monitoring simultaneously microbial load, specific pathogens and oyster immune status, we could demonstrate that: (i) susceptible oysters sense pathogens and signal an immune response during the mortality event, (ii) susceptible oysters do not express important antimicrobial and apoptotic mechanisms and show repressed expression of genes involved in ROS and metal homeaostasis, and (iii) this inefficient immune response enables major microbial colonization by bacteria and viruses including species potentially pathogenic for oysters. Our data also confirm the highly complex etiology of the juvenile oyster mortality syndrome which associates both viruses and vibrios, and potentially other bacteria massively proliferating in oyster flesh and intravalvular fluid during the mortality event. Understanding such a mulfifactorial disease is no exception call upons the development of integrated and multidisciplinary approaches [64] that will help deciphering the sequence of events leading to oyster mortalities and determining the relative weight of pathogens, oyster (genetics and phenotypic plasticity) and oyster-associated microbiota in disease expression and control.

\section{Acknowledgements}

The authors thank Marc Leroy for laboratory assistance at IHPE and Philippe Clair from the qPHD platform (Montpellier genomix) for useful advices. The authors also thank the staff 
involved in oyster production (Ifremer hatchery in La Tremblade and Ifremer nursery in Bouin). This work received financial support from the EC2CO (Ecosphère Continentale et Côtière) MicrobiEn and PNEC project MicroGigas (0405/1B1INEE).

\section{Author contributions}

JdL, JME, YG, DDG, and EB designed the experiment and drafted the manuscript. FP, PLG, and JdL designed and carried out the field experimentations. JdL and VL carried out the qPCR analyses. AV performed sample conditioning and RNA extractions. FA, JLJ, and EJ-B performed the quantification of culturable bacteria. PG performed the flow cytometry analyses. All authors read and approved the final manuscript.

\section{Figure caption}

Figure 1: Oyster mortalities monitoring during exposure in a culture area at Thau lagoon (France). Mortality were measured, at two dates before $\left(6^{\text {th }}\right.$ and $12^{\text {th }}$ of April $)$ and two dates after $\left(26^{\text {th }}\right.$ and $29^{\text {th }}$ of April) mortalities outbreak, on 8 months old oysters that were exposed for the first time to an infectious environment (in red) and 18 months old oysters that have already survived to a previous infectious episode (in bleu). Thau lagoon sea water temperature is indicated by black dotted curve.

\section{Figure 2: Susceptible oysters are highly permissive to bacterial colonization during in} situ mortality outbreak. 8 months old oysters exposed for the first time to an infectious environment (S) and 18 months old oysters that have already survived to a previous infectious episode (R) were analyzed. A: Abundance of total bacteria in intravalvular fluid was measured by flow cytometry at two dates (April $26^{\text {th }}$ and $29^{\text {th }} 2010$ ) during mortality outbreak. Abundance of total bacteria was measured in Thau lagoon sea water at the same dates (SW). Results are the mean of six biological replicas (six individuals for oysters and six samples for water), and significant differences of total bacteria abundance between conditions are indicated by different lowercase letters (different letters indicate significant difference, a or b; Mann-Whitney U test, $p<0.05)$. B: Abundances of cultivable bacteria in whole oyster flesh were determined by CFU count (on marine agar medium) at two dates (April $26^{\text {th }}$ and $29^{\text {th }}$ ) during mortality outbreak. Abundance of cultivable bacteria are determined from six individual oysters per condition and significant differences between conditions are indicated 
by different lowercase letters (different letters indicate significant difference, a, b or c; MannWhitney U test, $p<0.05)$.

437

Figure 3: Pathogen detections before and during mortality outbreak. Vibrio tasmaniensis LGP32 (A) and OsHV-1 (B) were quantified by qPCR according to the $2^{-\Delta \Delta C t}$ method [32] using a single copy gene of oyster genome $(C g-B P I)$ to normalize $\mathrm{Ct}$ values of target genes for Vibrio tasmaniensis LGP32 and for OsHV-1. Each relative value is the mean of tree biological replicas (tree pools of 10 oysters per condition) and significant differences of relative expressions between conditions are indicated by different lowercase letters (different letters indicate significant difference, a, b or c) and were determined by the (Mann-Whitney $\mathrm{U}$ test, $p<0.05) .8$ months old oysters exposed for the first time to an infectious environment (S) and 18 months old oysters that have already survived to a previous infectious episode (R) were analyzed.

Figure 4. Gene expression of 54 immune related genes differentially expressed during juvenile mortality. Hierarchical clustering of the relative expression levels of 54 immune related genes differentially expressed (one-way ANOVA, $p<0.05$ ) during mortality outbreak was constructed with Multiple Array Viewer software using average linkage clustering with Pearson Correlation as the default distance metric. Each cell in the matrix corresponds to the expression level of one gene in one sample. The intensity of the color from green to red indicates the magnitude of differential expression. Relative expressions were calculated according the $2^{-\Delta \Delta \mathrm{Ct}}$ method [32], from four groups of ten oysters per condition. The dendrogram at the top of the figure indicate relationship among samples and revealed a distinction between the tested conditions. The dendrogram at the left of the figure indicate a relationship among the relative expression levels of the selected genes. Selected genes, listed at the right of the figure. 
1. Samain J-F, McCombie H. Summer mortality of Pacific oyster Crassostrea gigas. The MOREST 465 project. QUAE ed; 2008.

4662 2. Pernet F, Lupo C, Bacher C, Whittington RJ. Infectious diseases in oyster aquaculture require 467 a new integrated approach. Philos Trans R Soc Lond B Biol Sci. 2016371.

468 3. Martenot C, Oden E, Travaille E, Malas JP, Houssin M. Detection of different variants of 469 Ostreid Herpesvirus 1 in the Pacific oyster, Crassostrea gigas between 2008 and 2010. Virus research. $470 \quad 2011$ 160:25-31.

471 4. Barbosa Solomieu V, Renault T, Travers MA. Mass mortality in bivalves and the intricate case of the Pacific oyster, Crassostrea gigas. J Invertebr Pathol. 2015 131:2-10.

5. Guo XM, Ford SE. Infectious diseases of marine molluscs and host responses as revealed by genomic tools. Philos T R Soc B. 2016371.

6. Paul-Pont I, Evans O, Dhand NK, Whittington RJ. Experimental infections of Pacific oyster Crassostrea gigas using the Australian ostreid herpesvirus-1 (OsHV-1) microVar strain. Dis Aquat Organ. 2015 113:137-47.

7. Domeneghetti S, Varotto L, Civettini M, Rosani U, Stauder M, Pretto T, et al. Mortality occurrence and pathogen detection in Crassostrea gigas and Mytilus galloprovincialis close-growing in shallow waters (Goro lagoon, Italy). Fish Shellfish Immunol. 2014 41:37-44.

8. Lynch SA, Carlsson J, Reilly AO, Cotter E, Culloty SC. A previously undescribed ostreid herpes virus 1 (OsHV-1) genotype detected in the pacific oyster, Crassostrea gigas, in Ireland. Parasitology. 2012 139:1526-32.

9. $\quad$ EFSA PoAHW. Scientific opinion on oyster mortality. EFSA Journal 2015 13:59.

10. Petton B, Pernet F, Robert R, Boudry P. Temperature influence on pathogen transmission and subsequent mortalities in juvenile Pacific oysters Crassostrea gigas. Aquaculture Environment Interactions. 2013 3:257-73.

11. Pernet F, Barret J, Le Gall P, Corporeau C, Dégremont L, Lagarde F, et al. Mass mortalities of Pacific oysters Crassostrea gigas reflect infectious diseases and vary with farming practices in the Mediterranean Thau lagoon, France. Acquaculture environmental interactions. 2012 2:215-37.

12. Pernet F, Lagarde F, Jeannee N, Daigle G, Barret J, Le Gall P, et al. Spatial and Temporal Dynamics of Mass Mortalities in Oysters Is Influenced by Energetic Reserves and Food Quality. Plos One. 20149.

13. Renault T, Bouquet AL, Maurice JT, Lupo C, Blachier P. Ostreid Herpesvirus 1 Infection among Pacific Oyster (Crassostrea gigas) Spat: Relevance of Water Temperature to Virus Replication and Circulation Prior to the Onset of Mortality. Appl Environ Microb. 2014 80:5419-26.

14. Le Roux F, Wegner KM, Polz MF. Oysters and Vibrios as a Model for Disease Dynamics in Wild Animals. Trends in microbiology. 2016 24:568-80.

15. Petton B, Boudry $P$, Alunno-Bruscia $M$, Pernet $F$. Factors influencing disease-induced mortality of Pacific oysters Crassostrea gigas. Acquaculture environmental interactions. 2015 6:20522.

16. Segarra A, Pepin JF, Arzul I, Morga B, Faury N, Renault T. Detection and description of a particular Ostreid herpesvirus 1 genotype associated with massive mortality outbreaks of Pacific oysters, Crassostrea gigas, in France in 2008. Virus research. 2010 153:92-9.

17. Gay M, Berthe FC, Le Roux F. Screening of Vibrio isolates to develop an experimental infection model in the Pacific oyster Crassostrea gigas. Dis Aquat Organ. 2004 59:49-56.

18. Le Roux F, Gay M, Lambert C, Waechter M, Poubalane S, Cholet B, et al. Comparative analysis of Vibrio splendidus-related strains isolated during Crassostrea gigas mortality events. . Aquatic Living Resources. 2002:251-8.

19. Lemire A, Goudenege D, Versigny T, Petton B, Calteau A, Labreuche $Y$, et al. Populations, not clones, are the unit of vibrio pathogenesis in naturally infected oysters. Isme J. 2014 9:1523-31.

20. Travers MA, Boettcher Miller K, Roque A, Friedman CS. Bacterial diseases in marine bivalves. J Invertebr Pathol. 2015 131:11-31. 
21. Jouaux $A$, Lafont $M$, Blin $\mathrm{JL}$, Houssin $M$, Mathieu $M$, Lelong $C$. Physiological change under OsHV-1 contamination in Pacific oyster Crassostrea gigas through massive mortality events on fields. BMC Genomics. 2013 14:590.

22. Petton B, Bruto $M$, James $A$, Labreuche $Y$, Alunno-Bruscia $M$, Le Roux F. Crassostrea gigas mortality in France: the usual suspect, a herpes virus, may not be the killer in this polymicrobial opportunistic disease. Front Microbiol. 2015 6:686.

23. Azema P, Lamy JB, Boudry P, Renault T, Travers MA, Degremont L. Genetic parameters of resistance to Vibrio aestuarianus, and OsHV-1 infections in the Pacific oyster, Crassostrea gigas, at three different life stages. Genetics, selection, evolution : GSE. 2017 49:23.

24. Dégremont L, Boudry $P$, Ropert $M$, Samain J-F, Bédier E, Soletchnik P. Effects of age and environment on survival of summer mortality by two selected groups of the Pacific oyster Crassostrea gigas. Aquaculture. 2010 299:44-50.

25. Azema P, Travers MA, Benabdelmouna A, Degremont L. Single or dual experimental infections with Vibrio aestuarianus and OsHV-1 in diploid and triploid Crassostrea gigas at the spat, juvenile and adult stages. J Invertebr Pathol. 2016 139:92-101.

26. Hick PM, Evans O, Rubio A, Dhand NK, Whittington RJ. Both age and size influence susceptibility of Pacific oysters (Crassostrea gigas) to disease caused by Ostreid herpesvirus -1 (OsHV-1) in replicated field and laboratory experiments. Aquaculture. 2018 in press.

27. Zhang G, Fang X, Guo X, Li L, Luo R, Xu F, et al. The oyster genome reveals stress adaptation and complexity of shell formation. Nature. 2012 490:49-54.

28. Green TJ, Vergnes A, Montagnani C, de Lorgeril J. Distinct immune responses of juvenile and adult oysters (Crassostrea gigas) to viral and bacterial infections. Veterinary research. 2016 47:72.

29. Chaney ML, Gracey AY. Mass mortality in Pacific oysters is associated with a specific gene expression signature. Mol Ecol. 2011 20:2942-54.

30. Duperthuy M, Binesse J, Le Roux F, Romestand B, Caro A, Got P, et al. The major outer membrane protein $\mathrm{OmpU}$ of Vibrio splendidus contributes to host antimicrobial peptide resistance and is required for virulence in the oyster Crassostrea gigas. Environ Microbiol. 2010 12:951-63.

31. Pepin JF, Riou A, Renault T. Rapid and sensitive detection of ostreid herpesvirus 1 in oyster samples by real-time PCR. J Virol Methods. 2008 149:269-76.

32. Pfaffl MW. A new mathematical model for relative quantification in real-time RT-PCR. Nucleic Acids Research. 2001 29:e45.

33. Marie D, Partensky F, Jacquet S, Vaulot D. Enumeration and Cell Cycle Analysis of Natural Populations of Marine Picoplankton by Flow Cytometry Using the Nucleic Acid Stain SYBR Green I. Appl Environ Microbiol. 1997 63:186-93.

34. Bouvy $M$, Got $P$, Domaizon I, Pagano $M$, Leboulanger $C$, Bouvier $C$, et al. Plankton communities in the five lles Eparses (Western Indian Ocean) considered to be pristine ecosystems. Acta Oecol. 2016 72:9-20.

35. Bouvier T, Del Giorgio PA, Gasol JM. A comparative study of the cytometric characteristics of high and low nucleic-acid bacterioplankton cells from different aquatic ecosystems. Environ Microbiol. 2007 9:2050-66.

36. Troussellier $M$, Got $P$, Bouvy $M, M^{\prime}$ Boup $M$, Arfi R, Lebihan $F$, et al. Water quality and health status of the Senegal River estuary. Marine pollution bulletin. 2004 48:852-62.

37. Paul-Pont I, Dhand NK, Whittington RJ. Spatial distribution of mortality in Pacific oysters Crassostrea gigas: reflection on mechanisms of OsHV-1 transmission. Diseases of Aquatic Organisms. 2013 105:127-38.

38. Lafont M, Petton B, Vergnes A, Pauletto M, Segarra A, Gourbal B, et al. Long-lasting antiviral innate immune priming in the Lophotrochozoan Pacific oyster, Crassostrea gigas. Sci Rep-Uk. 2017 7:13143.

39. Allam B, Pales Espinosa E. Bivalve immunity and response to infections: Are we looking at the right place? Fish Shellfish Immunol. 2016 53:4-12.

40. Lokmer A, Wegner KM. Hemolymph microbiome of Pacific oysters in response to temperature, temperature stress and infection. Isme J. 2015 9:670-82. 
41. Bruto $M$, James $A$, Petton $B$, Labreuche $Y$, Chenivesse $S$, Alunno-Bruscia $M$, et al. Vibrio crassostreae, a benign oyster colonizer turned into a pathogen after plasmid acquisition. Isme Journal. 2017 11:1043-52.

42. Vanhove AS, Rubio TP, Nguyen AN, Lemire A, Roche D, Nicod J, et al. Copper homeostasis at the host vibrio interface: lessons from intracellular vibrio transcriptomics. Environmental microbiology. 2016 18:875-88.

43. Lokmer A, Kuenzel S, Baines J, Wegner KM. The Role of Tissue-specific Microbiota in Initial Establishment Success of Pacific oysters. Environ Microbiol. 2016 18:970-87.

44. Wegner KM, Volkenborn N, Peter H, Eiler A. Disturbance induced decoupling between host genetics and composition of the associated microbiome. BMC Microbiol. 2013 13:252.

45. de Lorgeril J, Zenagui R, Rosa RD, Piquemal D, Bachere E. Whole transcriptome profiling of successful immune response to Vibrio infections in the oyster Crassostrea gigas by digital gene expression analysis. PLoS One. 2011 6:e23142.

46. Rosa RD, de Lorgeril J, Tailliez P, Bruno R, Piquemal D, Bachere E. A hemocyte gene expression signature correlated with predictive capacity of oysters to survive Vibrio infections. BMC Genomics. 2012 13:252.

47. Genard B, Miner P, Nicolas JL, Moraga D, Boudry P, Pernet F, et al. Integrative study of physiological changes associated with bacterial infection in Pacific oyster larvae. PLoS One. 2013 8:e64534.

48. Gerdol $M$, Venier P, Pallavicini A. The genome of the Pacific oyster Crassostrea gigas brings new insights on the massive expansion of the C1q gene family in Bivalvia. Dev Comp Immunol. 2015 49:59-71.

49. Itoh N, Okada Y, Takahashi KG, Osada M. Presence and characterization of multiple mantle lysozymes in the Pacific oyster, Crassostrea gigas. Fish Shellfish Immunol. 2010 29:126-35.

50. Jiang S, Li H, Zhang D, Zhang H, Wang L, Sun J, et al. A C1q domain containing protein from Crassostrea gigas serves as pattern recognition receptor and opsonin with high binding affinity to LPS. Fish Shellfish Immunol. 2015 45:583-91.

51. Schmitt $P$, de Lorgeril J, Gueguen $Y$, Destoumieux-Garzon D, Bachere E. Expression, tissue localization and synergy of antimicrobial peptides and proteins in the immune response of the oyster Crassostrea gigas. Dev Comp Immunol. 2012 37:363-70.

52. Wang L, Zhang $H$, Zhang D, LV Z, Liu Z, Wang W, et al. The RNA-seq analysis suggests a potential multi-component complement system in oyster Crassostrea gigas. Dev Comp Immunol. 2017 76:209-19.

53. Zhang L, Li L, Guo X, Litman GW, Dishaw LJ, Zhang G. Massive expansion and functional divergence of innate immune genes in a protostome. Sci Rep. 2015 5:8693.

54. Martenot C, Gervais O, Chollet B, Houssin M, Renault T. Haemocytes collected from experimentally infected Pacific oysters, Crassostrea gigas: Detection of ostreid herpesvirus 1 DNA, RNA, and proteins in relation with inhibition of apoptosis. PLoS One. 2017 12:e0177448.

55. Moreau P, Moreau K, Segarra A, Tourbiez D, Travers MA, Rubinsztein DC, et al. Autophagy plays an important role in protecting Pacific oysters from OsHV-1 and Vibrio aestuarianus infections. Autophagy. 2015 11:516-26.

56. Schmitt $P$, Santini A, Vergnes A, Degremont L, de Lorgeril J. Sequence polymorphism and expression variability of Crassostrea gigas immune related genes discriminate two oyster lines contrasted in term of resistance to summer mortalities. PLoS One. 2013 8:e75900.

57. Barshis DJ, Ladner JT, Oliver TA, Seneca FO, Traylor-Knowles N, Palumbi SR. Genomic basis for coral resilience to climate change. Proc Natl Acad Sci U S A. 2013 Jan 22;110(4):1387-92.

58. Green TJ, Montagnani C. Poly I:C induces a protective antiviral immune response in the Pacific oyster (Crassostrea gigas) against subsequent challenge with Ostreid herpesvirus (OsHV-1 muvar). Fish Shellfish Immunol. 2013 35:382-8.

59. He $\mathrm{Y}$, Jouaux A, Ford SE, Lelong $C$, Sourdaine $P$, Mathieu $M$, et al. Transcriptome analysis reveals strong and complex antiviral response in a mollusc. Fish Shellfish Immunol. 2015 46:131-44. 
617 60. Normand J, Li R, Quillien V, Nicolas JL, Boudry P, Pernet F, et al. Contrasted survival under 618 field or controlled conditions displays associations between mRNA levels of candidate genes and 619 response to OsHV-1 infection in the Pacific oyster Crassostrea gigas. Mar Genomics. 2014 15:95-102.

620 61. Segarra A, Mauduit F, Faury N, Trancart S, Degremont L, Tourbiez D, et al. Dual 621 transcriptomics of virus-host interactions: comparing two Pacific oyster families presenting 622 contrasted susceptibility to ostreid herpesvirus 1. BMC Genomics. 2014 15:580.

623 62. Fleury E, Huvet A. Microarray analysis highlights immune response of pacific oysters as a 624 determinant of resistance to summer mortality. Mar Biotechnol (NY). 2012 14:203-17.

625 63. Rosani U, Varotto L, Domeneghetti S, Arcangeli G, Pallavicini A, Venier P. Dual Analysis of 626 Host and Pathogen Transcriptomes in Ostreid Herpesvirus 1 - Positive Crassostrea gigas. Environ 627 Microbiol. 2014 17:4200-12.

628 64. Destoumieux-Garzón D, Mavingui P, Boetsch G, Boissier J, Darriet F, Duboz P, et al. The One 629 Health Concept: 10 Years Old and a Long Road Ahead. Front. Vet. Sci. 2018. 5:14. 


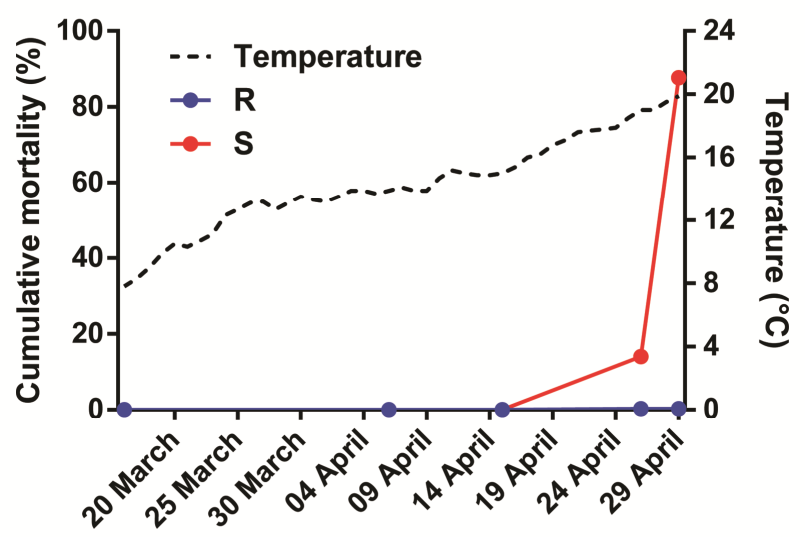

Date 
A

$\frac{\frac{S W \quad \mathrm{R} \quad \mathrm{S}}{26 \text { April }}}{\text { During mortality event }}$

B

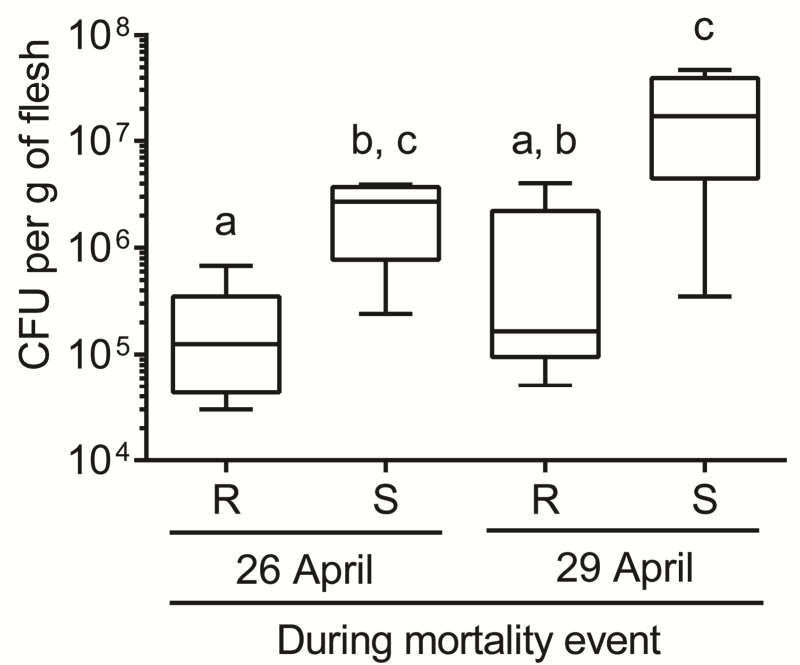



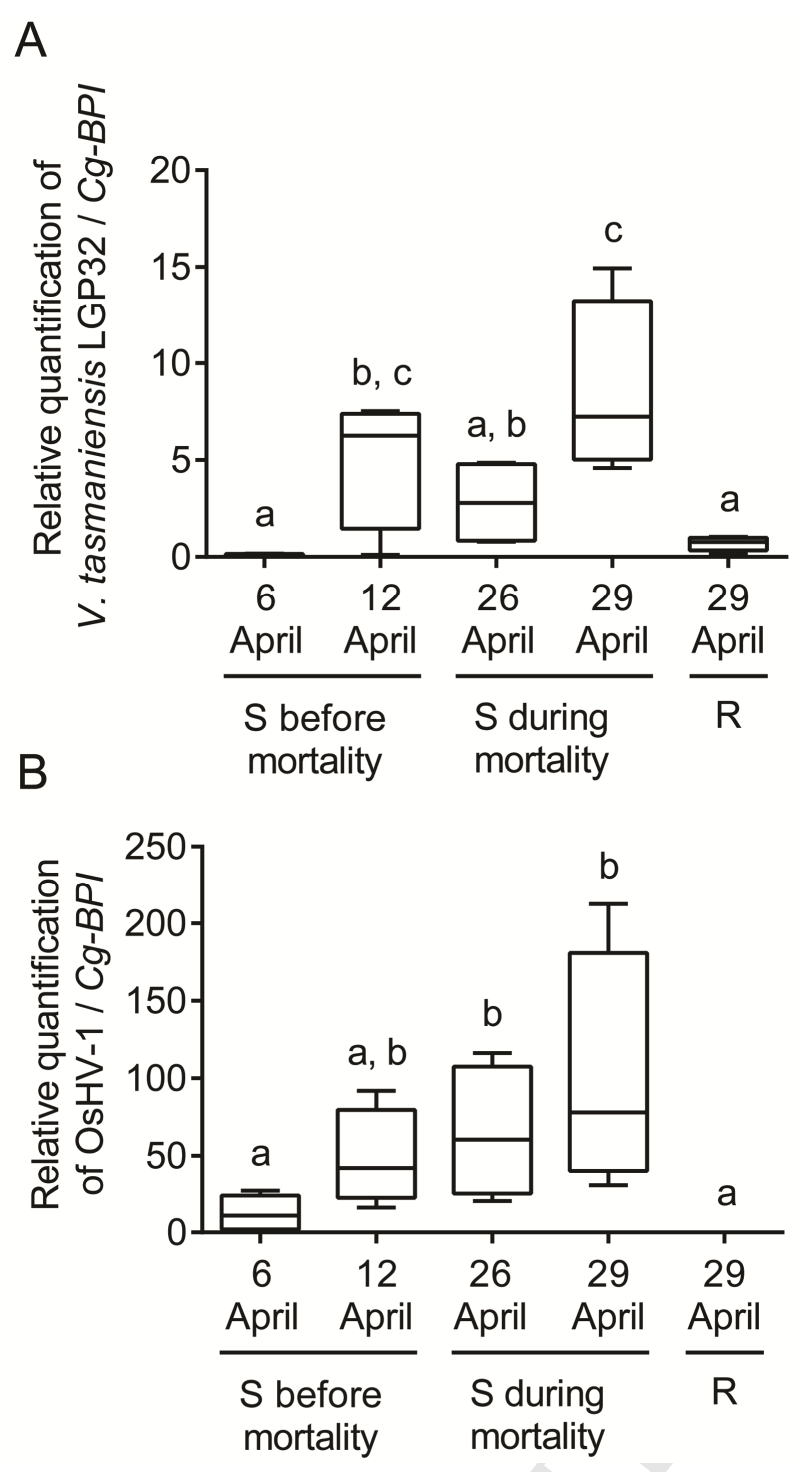


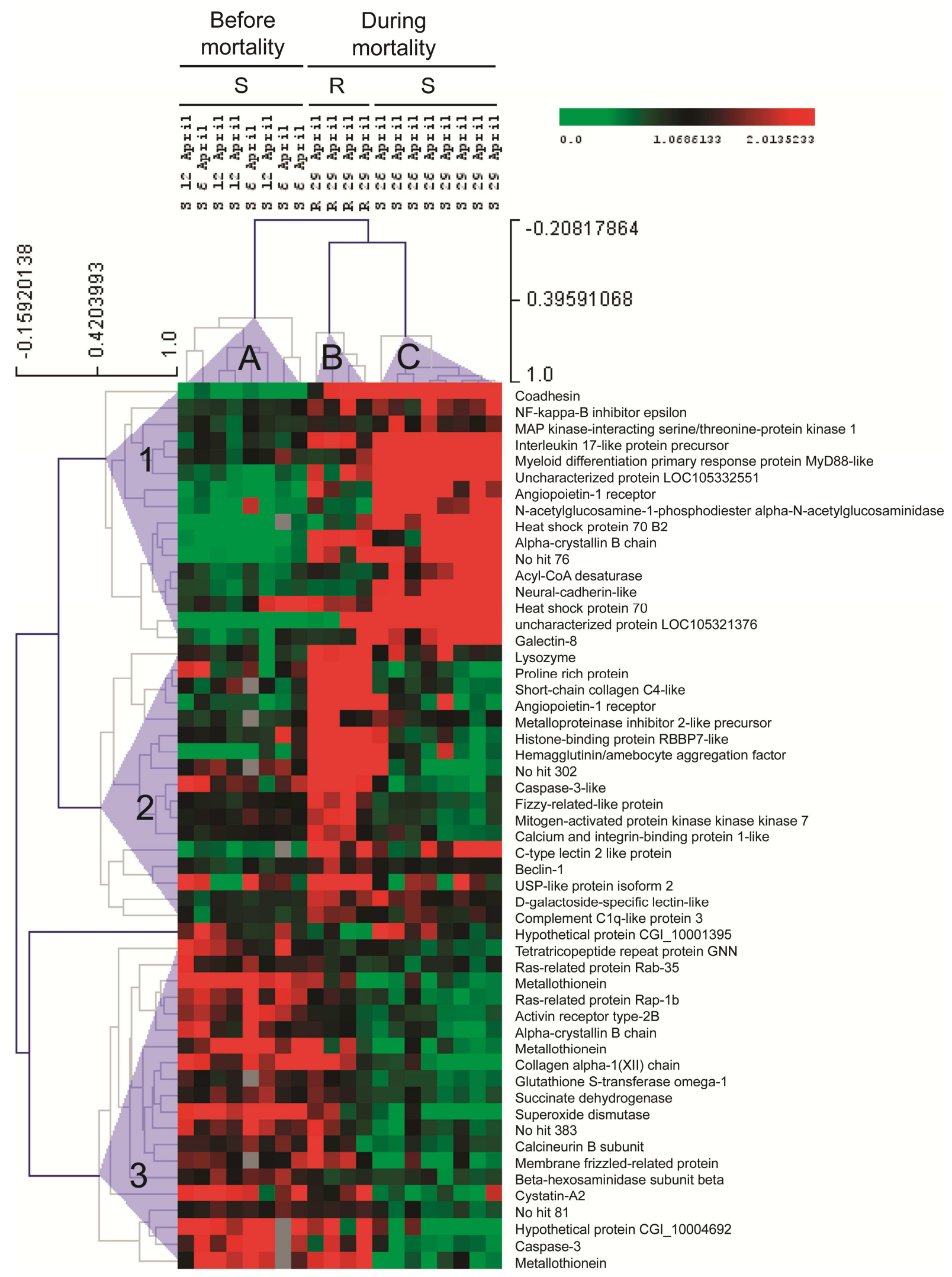




\section{Highlights}

- Juvenile oysters susceptible to the disease mount an inefficient immune response associated with microbial permissiveness and death

- Susceptible oysters were heavily colonized by OsHV-1 herpes virus as well as bacteria including vibrios potentially pathogenic for oysters

- Adult oysters resistant to the disease expresses important immune effectors, controlled bacterial and viral colonization and survived to the mortality event. 